\begin{tabular}{|c|c|c|c|c|c|c|}
\hline \multirow{4}{*}{ Impact Factor: } & ISRA (India) & $=3.117$ & SIS (USA) & $=0.912$ & ICV (Poland) & $=6.630$ \\
\hline & ISI (Dubai, UAE & $=\mathbf{0 . 8 2 9}$ & РИНЦ (Russia & $=0.156$ & PIF (India) & $=1.940$ \\
\hline & GIF (Australia) & $=0.564$ & ESJI (KZ) & $=8.716$ & IBI (India) & $=4.260$ \\
\hline & JIF & $=1.500$ & SJIF (Morocco & $=5.667$ & OAJI (USA) & $=0.350$ \\
\hline
\end{tabular}

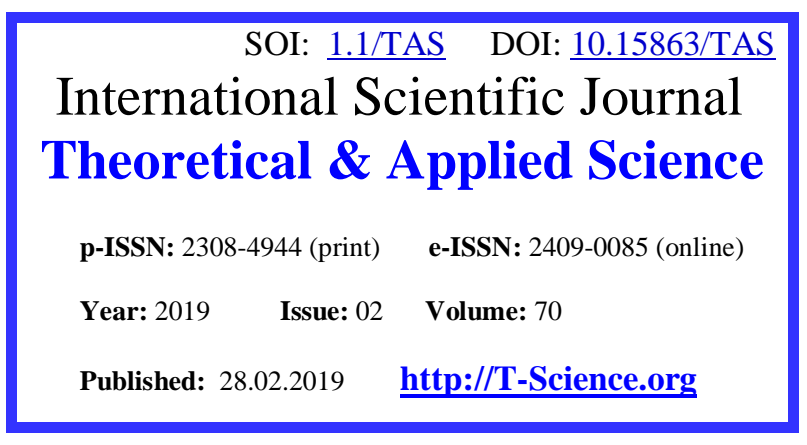

SECTION 31. Economic research, finance, innovation, risk management.
QR - Issue

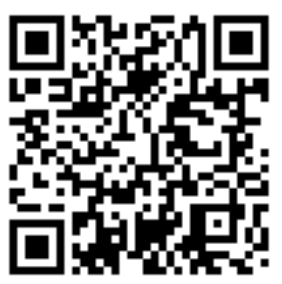

QR - Article

\title{
ROLE OF VOLUNTEER ACTIVITIES IN THE EDUCATION OF SOCIAL ACTIVITY OF YOUTH: IN CASE OF RUSSIA
}

Abstract: In the article reveals the essence of the concept of volunteering, studied the features of the volunteer movement in the life of young people in Russia. In addition, the author paid attention to the organization of volunteering in higher education as an important component of the process of socialization of students, their social activity. Analyzed the experience of organizing volunteer activities of students in Russia.

Key words: volunteer, social protection, youth, volunteer movement, volunteering.

Language: English

Citation: Abdulhaeva, J. J. (2019). Role of volunteer activities in the education of social activity of youth: in case of Russia. ISJ Theoretical \& Applied Science, 02 (70), 278-282.

Soi: http://s-o-i.org/1.1/TAS-02-70-27 Doi: crossef https://dx.doi.org/10.15863/TAS.2019.02.70.27

\section{Introduction}

One of the most notable trends that have emerged in recent years is the growth of volunteering (volunteering). Volunteering (volunteering) is the participation of people, regardless of age, race, gender, and religion, in activities aimed at solving social, cultural, economic, environmental problems in society that are not related to making a profit. Youth volunteering is a practical volunteer activity of young people on the substantive solution of social problems, carried out without coercion and exerting a socializing influence on the subject of activity.

\section{Literature review}

The phenomenon of social activity of a person can be considered a very multifaceted and multidimensional phenomenon. Accordingly, approaches to the study and study of this phenomenon are also distinguished by the diversity, the availability of alternative views and positions. In Russian science, more and more studies appear in which the phenomenon of social activity of the individual is considered in context A. V. Belyaev, A. S. Gayazov, O. V. Lesher, A. Nicholls [7], S. McBreaty [8], S. Prabhuddhanitisarn [9], M. Royce [10], P.N. Bloom [11] and others. It should be noted that, according to the assessments of many authors investigating the problem under consideration, a special role in this process belongs to children's and youth's public associations.
Analysis of the literature on the problem of social and pedagogical activity of the volunteer movement allows us to identify a number of contradictions in the application of this experience in Russia [1]. Among the most significant are the contradictions:

- between the growing role of the volunteer movement in the social development of society and the insufficient development of its theoretical foundations, the mechanisms for its effective application in Russian social work;

- between the need of modern society for socially active youth and insufficient use of the educational opportunities of the volunteer movement;

- between the real possibility of studying the experience of the volunteer movement and the lack of extensive testing of these models in the practice of Russian nongovernmental organizations.

Referring to the very definition of "volunteering", it should be noted that volunteering is a concept as ancient as the concept "society". In society there have always been people for whom the way of self-redemption, self-improvement, communication and communication with other people was work for the benefit of others, for the benefit of the community in which this person happened to be born and live [3].

The volunteer movement emerged and developed in the 1920s. in Europe [4]. And in subsequent years, the volunteer movement became 


\begin{tabular}{|c|c|c|c|c|c|c|}
\hline \multirow{4}{*}{ Impact Factor: } & ISRA (India) & $=3.117$ & SIS (USA) & $=0.912$ & ICV (Poland) & $=6.630$ \\
\hline & ISI (Dubai, UAE & $=0.829$ & РИНЦ (Russia & $=0.156$ & PIF (India) & $=1.940$ \\
\hline & GIF (Australia) & $=0.564$ & ESJI (KZ) & $=8.716$ & IBI (India) & $=4.260$ \\
\hline & JIF & $=1.500$ & SJIF (Morocco & $=5.667$ & OAJI (USA) & $=0.350$ \\
\hline
\end{tabular}

even more widespread among both young people and older people. Since then, volunteering has gained momentum and popularity around the world.

\section{Analysis and results}

Currently, a large role in the development of volunteer volunteer activities is played by student youth. Volunteer detachments, organizations and movements emerge and develop among students. Volunteering as a youth movement in Russia is only gaining momentum in development. In many cities, it plays an important role. The city of Krasnodar is a platform for consolidating the efforts of public organizations, authorities in the development of volunteering - one of the priorities for the implementation of state youth policy at the municipal level. According to the order of the Department of Youth Policy of the Krasnodar Territory "On the organization of volunteer (volunteer) activities in the Krasnodar Territory" dated June 1, 2010 No. 183 [1], volunteer centers were opened in many higher educational institutions of Kuban. The main objectives of these centers are: providing opportunities for young people to express themselves, to realize their potential; formation of social value of volunteering (volunteering) and positive public opinion regarding the participation of young citizens in voluntary (volunteer) activities; development of a system of information and consulting and educational support for volunteer activities.

On May 14, 2011, the KubSU Volunteer Center officially started work at the Kuban State University (KubSU). For the Olympic Games in Sochi, the KubSU Volunteer Center should prepare and train 2,850 volunteers. The volunteer center united in itself 25 volunteer groups of various faculties of the university. According to the Center, over the past three years, more than 4,500 students, teachers and KubSU employees have taken part in 32 social events.

The mission of the KubSU Volunteer Center is to promote volunteering, motivate and attract young people to volunteer to promote Olympic values for the common good and enhance social capital of Russia, to shape its attractive image in the global community. Teachers, lawyers, specialists in public relations, narcologists, specialists in working with young people, employees of the scientific library, etc. work with volunteer students at the Kuban State University. The purpose of this work is to gain experience in volunteer work and then independently work in youth environment.

Among the motives of voluntary (volunteer) activities, public motives can be distinguished (high demands on oneself, colleagues, results of one's work, sense of responsibility, duty, patriotism, compassion, etc.), cognitive motives, pragmatic motives, passion for external signs, motives of imitation.

The main reasons for volunteering are: the realization of personal potential, the manifestation of their abilities and capabilities, the realization of human destiny.

These are the leading motives of human participation in socially significant activities. An important role in the maintenance of this motivation belongs to the awareness of a man of his own inner potential, the definition of personal mission, the choice of life.

Public recognition, a sense of social significance. It is important for a person to get a positive reinforcement of his activities from significant surrounding people, to establish himself in his own eyes, to feel his involvement in the common good cause. The basis of this motivation is the human need for high self-esteem and evaluation by others. This assessment plays an important role in the choice of goals and objectives of their own activities, the direction of personal growth. Self-expression and self-determination. An opportunity to express oneself, to declare one's life position, to find one's place in the system of social relations. The need of a person to realize his own individuality, the uniqueness of his inner world and the desire to fulfill a role in society, according to his individuality, is the basis of the motivation for selfexpression and self-determination.

Professional orientation. Volunteering allows a person, especially a young person, to better orient themselves in various types of professional activity, to get a real idea of the intended profession or to choose the direction of vocational training. Acquisition of useful social and practical skills. Volunteering (volunteering) activity allows you to acquire useful skills that are not directly related to the professional choice of a person, but are important for life. These include the acquisition of computer skills, with various types of technology, construction skills, experience of interpersonal interaction. The need for an activity and social development of the world around us, for the use of all the opportunities provided to society by man is one of the urgent needs of the modern man.

The possibility of communication, friendly interaction with like-minded people. Volunteering allows you to acquire like-minded people, find a significant circle of contacts for yourself and get support in friendly interaction. One of the deepest human needs is the need to be accepted and involved in personally meaningful social relationships. 


\begin{tabular}{|c|c|c|c|c|c|c|}
\hline \multirow{4}{*}{ Impact Factor: } & ISRA (India) & $=3.117$ & SIS (USA) & $=0.912$ & ICV (Poland) & $=6.630$ \\
\hline & ISI (Dubai, UAE & $=0.829$ & РИНЦ (Russia) & $=0.156$ & PIF (India) & $=1.940$ \\
\hline & GIF (Australia) & $=0.564$ & ESJI (KZ) & $=8.716$ & IBI (India) & $=4.260$ \\
\hline & JIF & $=1.500$ & SJIF (Morocco) & $=5.667$ & OAJI (USA) & $=0.350$ \\
\hline
\end{tabular}

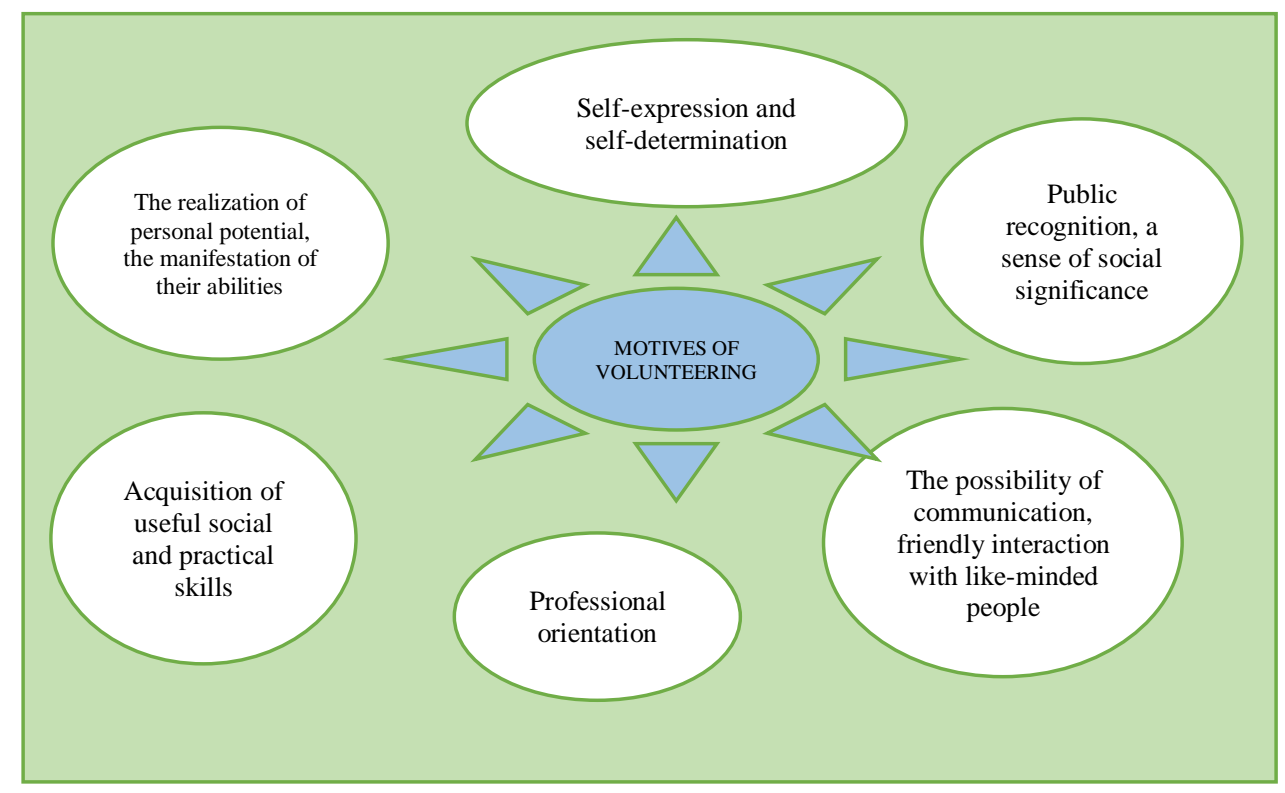

Picture 1. Motives of volunteering.

Volunteering gives a young person the opportunity to express themselves in various models of interaction, to acquire the skills necessary in later life for responsible leadership and performing activities. The need to gain experience of responsible interaction is a conscious social need. The experience of recent years, both in Russia and in the world as a whole, shows that to solve problems in the prevention of social maladjustment, it is necessary to attract not only professionals but also volunteers, whose methods of work in the surrounding society are often more effective. We agree with the opinion of many researchers that volunteer volunteering can be viewed as an important condition and an effective means of enhancing the social activity of young students.

Positive changes in recent years in the field of social policy in the Russian Federation, the achievement of stability in other areas of life to some extent contributes to the improvement of the moral and psychological state of the population. As a result, these social changes have largely affected the motivation of volunteering.

The analysis of literary sources on the problem of volunteering, our own research allows us to highlight a number of individual needs, on which the motives for participation in volunteer activity are based:

1) the need for recognition;

2) the need to achieve;

3) the need for self-control;

4) the need for diversity;

5) the need for growth;

6) the need for communication;

7) the need for entertainment.
It is obvious that social work with young people should be based on stimulating the activity of young people themselves, creating conditions for independent solution of the problems they face. This kind of work, aimed at the inclusion of the younger generation in social activity, albeit with an ideological bias, has quite successfully been carried out by children's and youth public organizations that function in all Soviet educational institutions. But, in the $90 \mathrm{~s}$, as a result of the drastically changing sociopolitical and economic situation in the country, the ideological situation also changed. The entire positive experience of working with young people accumulated over decades has been brought to oblivion, rast-ryan. In the entire post-Soviet space, a kind of vacuum has been formed, a worthy alternative has not been proposed. With the years, the state of affairs in this direction, though slowly, began to improve. In recent years, the number of people who come to non-profit organizations has increased in order to gain the necessary work experience, knowledge and skills, and the realization of their ideas. In this case, volunteering, or otherwise volunteering, can be considered as a powerful innovative means of professional socialization, which has a huge educational potential. The principle of gratuitousness and solidarity lies at the heart of volunteer activities, thus, its motives are rooted not in material remuneration, but in the satisfaction of social and spiritual needs. Volunteering is an unpaid, conscious, voluntary activity for the benefit of others. Anyone who works conscientiously and disinterestedly for the benefit of others can be called a volunteer.

Volunteering can be aimed at achieving pedagogical goals, becoming an important factor in 


\begin{tabular}{|c|c|c|c|c|c|c|}
\hline \multirow{4}{*}{ Impact Factor: } & ISRA (India) & $=3.117$ & SIS (USA) & $=0.912$ & ICV (Poland) & $=6.630$ \\
\hline & ISI (Dubai, UAE & $=0.829$ & РИНЦ (Russia & $=0.156$ & PIF (India) & $=1.940$ \\
\hline & GIF (Australia) & $=0.564$ & ESJI (KZ) & $=\mathbf{5 . 0 1 5}$ & IBI (India) & $=4.260$ \\
\hline & JIF & $=1.500$ & SJIF (Morocco & $=5.667$ & OAJI (USA) & $=0.350$ \\
\hline
\end{tabular}

educating students and young people [5. P. 12]. In modern Russia, it is an initiative children's-youth social movement that uses volunteer activities in teaching practice, can be one of the most important means of shaping the social activity of young people. In our small study as an object, we took student youth. Age turns out to be a significant factor in public interest. Describing this age category, it should be noted that this age is characterized by a desire for a new, unusual, risky, which leads to asocial forms of behavior. Due to age characteristics, the interests of young people do not completely coincide with the interests of society as a whole, and the lack of life experience increases the likelihood of erroneous choices when making responsible decisions. The growth of extremism and aggression in the youth environment, the formation of asocial subcultures and countercultures - testify to the insufficient effectiveness of the existing institutions of socialization, demonstrate their systemic crisis [2].

One of the most effective means of preventing and correcting the deviant behavior of young people is to support their initiatives, primarily related to selfemployment, self-education, and the possibility of obtaining early professional orientation. Self-initiated social activity of young people is a means of their livelihood and economic independence, a way of self-determination, asserting themselves as individuals, the ability to test and develop skills and business skills, the process of accumulation of life and business experience.

In her study on the analysis of the experience of organizing volunteer activities, L. E. Sikorskaya highlights the leading socially significant motives of her [6].

The first group of motives is the self-realization of personal potential, the possibility of the manifestation of their abilities and capabilities in socially significant social activities.

The next important group is public recognition, a sense of social significance, an opportunity to establish oneself in one's own eyes, to feel participation in a socially useful cause.

The author defines another group of motives as self-expression and self-determination. Volunteer work allows a person to express his inner "I" and affirm his life values.

The possibility of communication, friendly interaction with like-minded people. Gaining experience of responsible leadership and social interaction. Volunteer work allows you to acquire the skills you need in later life for responsible leadership and executive activities.

The ability to express a civil attitude in an active way to defend one's own views and values.
Fulfillment of public and religious duty. This need stems from a special knowledge of religious and ethical duty and testifies to a high personal development.

One of the features of volunteering is its integration into the sphere of social work. The problem is that the volunteer work of the students is mostly spontaneous, and the volunteer activity itself is often viewed primarily as a service. Therefore, a theoretical understanding of the possibilities and conditions for the organization of student volunteering as a means of their professional development is required. We assume that the high school has a sufficient degree of potential to use volunteerism as an effective means of increasing social activity and fulfilling the tasks of professional socialization of students.

\section{Conclusion}

So, as a result of the conducted research and its analysis, we can formulate some preliminary conclusions:

1. Active participation in volunteering will contribute to the development of social skills such as:

- communication skills;

- experience of responsible interaction;

- leadership skills;

- self-organization;

- performing discipline;

- protection and upholding of rights and interests;

- experience with the group;

- organizational skills;

- initiative and others.

2. Volunteer activities of students contribute to the increase of social activity, the solution of a promising task of forming future professionals of social work.

3. Social work with young people should be carried out in the constituent entities of the Russian Federation variably, taking into account the specifics of the regions and local conditions, but with unconditional observance of basic federal standards.

4. An important requirement for working with youth should be the creation of conditions for the exchange of work experience, the promotion of volunteer associations and the volunteer movement in general through the media.

5. In order to ensure the motivation of volunteers, it is necessary to encourage volunteer activities in the form of social and state benefits, recognition and improvement of volunteer status in society 


\begin{tabular}{|c|c|c|c|c|c|c|}
\hline \multirow{4}{*}{ Impact Factor: } & ISRA (India) & $=3.117$ & SIS (USA) & $=0.912$ & ICV (Poland) & $=6.630$ \\
\hline & ISI (Dubai, UAE & $=0.829$ & РИНЦ (Russia & $=0.156$ & PIF (India) & $=1.940$ \\
\hline & GIF (Australia) & $=0.564$ & ESJI (KZ) & $=\mathbf{5 . 0 1 5}$ & IBI (India) & $=4.260$ \\
\hline & JIF & $=1.500$ & SJIF (Morocco & $=5.667$ & OAJI (USA) & $=0.350$ \\
\hline
\end{tabular}

\section{References:}

1. Arovich, Y. (2009). Methods of work with volunteers. In ed. by M. Yu. Kiselev, I. I. Komarova (Eds.). School of the social management: Collection of articles. Moscow: Karapuz.

2. Belyaev, A. V. (2007). Socio-pedagogical bases of forming the civic consciousness of students. Author. Diss. ... Doctor of Pedagogy. (p.253). Ekaterinburg.

3. Bodrenkova, G. P. (2011). Systematic development of youth volunteering. Methodical recommendations. Moscow: AST.

4. Gagarina, V. V. (2007). Volunteer - it sounds good! Bulletin of the charity, \# 10.

5. Dubchenko, E. (2010). System development of volunteering in Russia: best practices. Moscow: DeKa.

6. Si-korskaya, L. E. (2011). Pedagogical potential of volunteerism of students. Knowledge. Understanding. Skill, \# 2, 213-217.
7. Nicholls, A. (2006). Social entrepreneurship: New models of sustainable social change. Oxford University Press, Inc, New York, NY.

8. McBreaty, S. (2007). The social enterprise-a solution for the voluntary sector. Social Enterprise Journal, 3 (1), 67-77.

9. Prabhuddhanitisarn, S., Onthoum, S., Cha ame, P., Chairacha, A., Dhumrongsakul, N., \& Onthoum, T. (2005). Research project for society development on children, assessment of conditional and problem solving process on children and youth in northern Thailand (RDC4640007) The Thailand Research Fund (TRF), Bangkok, Thailand.

10. Royce, M. (2007). Using human resource management tools to support social enterprise: Emerging themes from the sector. Social Enterprise Journal, 3 (1), 10-19.

11. Bloom, P. N., \& Chatterij, A. K. (2009). Scaling social entrepreneurial impact. California Management Review, 51 (3), 114133. 